\title{
An outline on Shweta pradara and An observational study on its clinical presentation
}

\author{
Research Article
}

Vishwesh BN1*

1. Associate Professor,

Department of Prasuti Tantra, Faculty of Ayurveda, IMS, BHU, Varanasi.

\begin{abstract}
Leucorrhoea is one of the commonest complaints among women of reproductive age group. An increase in the normal vaginal secretion develops physiologically at puberty, at ovulation, premenstrual phase and during pregnancy. Excessive discharge causes irritation and itching in the genitalia. Ayurveda explains this condition as Shwetha pradara. Though it is not a separate disease, clinically it has great relevance. This paper is an attempt to outline the details of Shwetha pradara as described in the classics and to illustrate its clinical presentation in 50 patients as an observational study.
\end{abstract}

Key Words: Leucorrhoea, Shwetha pradara, Vaginal secretion, Yoni srava.

\section{Introduction}

Leucorrhoea is an abnormal, nonhemorrhagic vaginal discharge which may be white, yellow or greenish in colour, accounting for more than an estimated of $25 \%$ of patients visits to gynaecologist. (1) Physiologically, some amount of vaginal discharge may be noted in various phases of menstrual cycle of a female depending upon the changes in the vaginal epithelium; bacterial flora and $\mathrm{pH}$ of the vagina. (2) Anyhow, when physiological, it is not associated with any other symptoms apart from discharge. But when it turns into a pathological condition, the female complains of associated problems like itching and burning sensation of the genitalia, lower abdominal pain, urinary disturbances, dyspareunia, discomfort, low back ache etc. (3) On microbiological examination, infections with organisms like Trichomonas vaginalis, Candida albicans, mixed bacterial infections, Monilial infections, etc have all been associated with leucorrhoea. (4) Though this disease condition does not cause morbidity or mortality in a female, health and efficiency of women are affected at large. The response to treatment is also not quick and requires constant consultation. The concept of leucorrhoea is explained under Shweta pradara in Ayurveda. Several approaches are explained in Ayurveda regarding the same. In this paper, it is proposed to outline the presentation of shweta pradara as explained in Ayurveda and observe the presence of its

* Corresponding Author:

Vishwesh BN

Associate Professor,

Department of Prasuti Tantra,

Faculty of Ayurveda,

IMS, BHU, Varanasi-221005

Email Id: vishweshbn@gmail.com symptomatology in the form of an observational study in 50 patients.

\section{Nirukti of the term Shweta pradara:}

Shweta means anything which is white in colour. Pradara means excess or in increased quantity, which indicates excessive flow. (5) Hence the combined term Shweta pradara means excessive white discharge per vagina.

Different varieties of vaginal discharges are explained under different context of pradara. An attempt is made to summarise the various types of vaginal discharge on the basis of consistency, colour \& smell etc, in Table 1.

Table.1: Types of Vaginal discharge as explained in Ayurvedic classics

\begin{tabular}{l|l} 
Tanu (thin) (6) & $\begin{array}{l}\text { The discharge is thin or watery } \\
\text { and noticed when there is } \\
\text { vitiation of Vata dosha. }\end{array}$ \\
$\begin{array}{l}\text { Shweta } \text { (White), } \\
\text { Sakapha (7) }\end{array}$ & $\begin{array}{l}\text { The discharge is thick and } \\
\text { mucoid. It involves vitiation of } \\
\text { kapha dosha. }\end{array}$ \\
$\begin{array}{l}\text { Snigdha } \\
\text { (unctuous)(8) }\end{array}$ & The discharge is unctuous. \\
$\begin{array}{l}\text { Vidagdha (burnt } \\
\text { like), peeta (9) }\end{array}$ & $\begin{array}{l}\text { The discharge is muco-purulent. } \\
\text { It mainly involves vitiation of } \\
\text { kapha and pitta. }\end{array}$ \\
\hline $\begin{array}{l}\text { Picchhila } \text { (slimy) } \\
\text { (10) }\end{array}$ & $\begin{array}{l}\text { The discharge is slimy. It is } \\
\text { found when there is vitiation of } \\
\text { kapha accompanied with vata. } \\
\text { The discharge is a purulent one. }\end{array}$ \\
\hline $\begin{array}{l}\text { Durgandhi } \\
\text { (purulent) (11) }\end{array}$ & $\begin{array}{l}\text { Noted in vitiation of all the } \\
\text { three dosha. }\end{array}$
\end{tabular}

There is no reference for the terminology "Shweta Pradara" in the Brihatrayee - the three main treatises of Ayurveda. Anyhow, Cakrapanidatta, the 
commentator of Charaka Samhita has explained Shwetapradara as pandura pradara (12) and Indu, the commentator of Ashtanga Sangraha explains it as shukla asrigdara.(13). There is a mentioning of Shweta pradara in the later text books of Ayurveda like Sharangadhara Samhita (14), Bhava Prakash, (15) Yoga Ratnakara (16) in the context of yoni srava. Anyhow in all these references, it has not been explained as a separate disease entity, but as a symptom of an underlying pathology. Inspite of this, Shweta pradara seeks maximum attention from the physicians as, irrespective of the underlying pathology, patients come to seek treatment giving utmost importance to this symptom and moreover, it still remains to be a challenge to the gynaecologists. The various disorders in which Shweta pradara exhibits itself as a symptom are explained in table.2.

Table 2: Disorders where Shweta pradara is a main symptom

\begin{tabular}{|c|c|}
\hline Yoni vyapat & Lakshanas \\
\hline $\begin{array}{l}\text { Kaphaja } \\
\text { yonivyapat (17) }\end{array}$ & $\begin{array}{l}\text { Picchila (slimy), kanduyukta } \\
\text { (associated with itching), } \\
\text { atisheetala ( cold) and } \\
\text { alpavedana (less pain) }\end{array}$ \\
\hline $\begin{array}{l}\text { Sannipatika } \\
\text { Yonivyapat or } \\
\text { Tridoshaja or } \\
\text { Sarvaja } \\
\text { yonivyapat (18) }\end{array}$ & $\begin{array}{l}\text { When the condition involves all } \\
\text { the doshas (biohumours), it } \\
\text { presents with shweta (white) and } \\
\text { picchila (slimy) discharge along } \\
\text { with daha (burning sensation) } \\
\text { and shola (pain). }\end{array}$ \\
\hline $\begin{array}{l}\text { Upapluta } \\
\text { yonivyapat (19) }\end{array}$ & $\begin{array}{l}\text { White mucoidal discharge } \\
\text { (shweta, sakapha) white (pandu) } \\
\text { discharge associated with } \\
\text { pricking pain. }\end{array}$ \\
\hline $\begin{array}{l}\text { Aticharana } \\
\text { yonivyapat } \\
\text { Acharana } \\
\text { yonivyapat } \\
\text { Atyananda } \\
\text { yonivyapat } \\
\text { Karnini } \\
\text { yonivyapat }(20)\end{array}$ & $\begin{array}{l}\text { Even though the cardinal } \\
\text { symptoms of these four } \\
\text { yonivyapat are different, kandu } \\
\text { (itching) and paicchhilya } \\
\text { (sliminess) are in common as all } \\
\text { these are due to predominance of } \\
k \text { a } h a, \text { a } \mathrm{d} \text { th e t e r m } \\
\text { "paicchhilya" refers to discharge. }\end{array}$ \\
\hline $\begin{array}{l}\text { Prasramsini } \\
\text { yonivyapat }(21)\end{array}$ & $\begin{array}{l}\text { One of its features includes- } \\
\text { Syandate- meaning- sravati- } \\
\text { indicating towards vaginal } \\
\text { discharge. }\end{array}$ \\
\hline $\begin{array}{l}\text { Pittala } \\
\text { yonivyapat }(22)\end{array}$ & $\begin{array}{l}\text { May be associated with purulent } \\
\text { vaginal discharge. }\end{array}$ \\
\hline
\end{tabular}

Shweta pradara usually exhibits itself as the main presenting symptom of an underlying pathology, and hence its etiopathogenesis would be that of the principal disease. However, on the basis of the clinical features it exhibits, the following etiopathogenesis may be considered.

\section{Samprapti of Shweta pradara: (Etiopathogenesis)}

The samprapti can be explained as depicted in the flow chart below:

\section{Flow Chart 1}

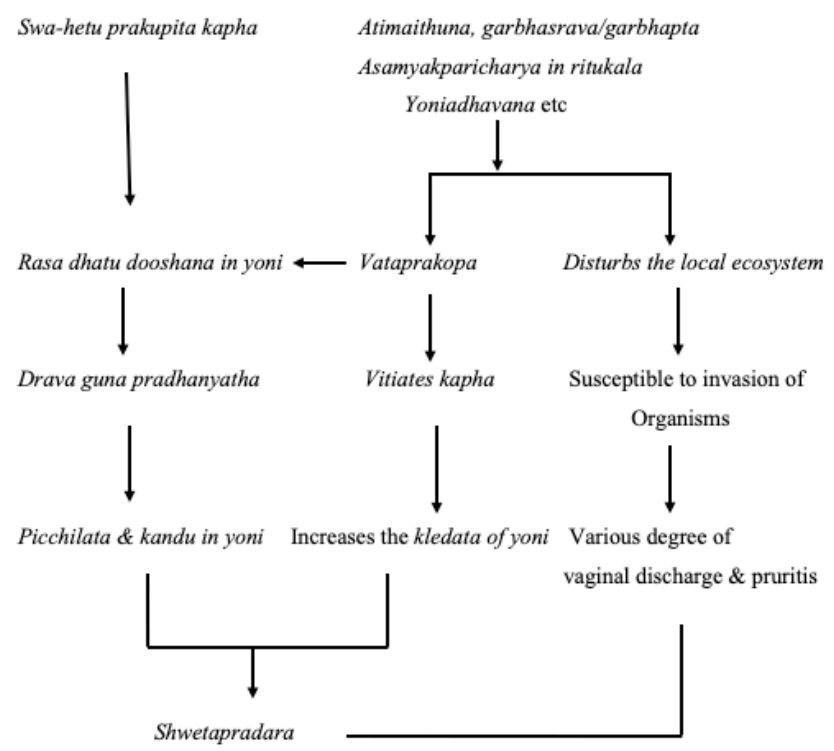

Samprapti ghataka: (Component of Pathogenesis)

- Dosha : Kapha, Vata.

- Dhatu: Rasa, Rakta

- Srotas: Artavavaha srotas.

- Rogamarga : Abhyantara.

- Adhistana : Yoni , Garbhashaya

- Sroto Dusti : Atipravritti

- Vyakthasthana: Yoni

\section{Chikitsa (Treatment)}

The treatment modality of Shweta pradara involves the Abhyantara (internal administration) and Bahya prayogas (external administration). The drugs used for internal administration are described in table.3.

Table 3: Drugs used in Abhyantara prayoga (Internal administration):

\begin{tabular}{|l|l|l|l|}
\hline $\begin{array}{l}\text { S. } \\
\text { No }\end{array}$ & Drug & $\begin{array}{l}\text { Scientific } \\
\text { source }\end{array}$ & Reference \\
\hline $\mathbf{1}$ & $\begin{array}{l}\text { Amalaki choorna } \\
\text { with Honey }\end{array}$ & $\begin{array}{l}\text { Emblica } \\
\text { officinalis } \\
\text { Gaertn }\end{array}$ & $\begin{array}{l}\text { Charaka } \\
\text { Samhita, } \\
\text { Chikitsa } \\
\text { sthana, } \\
\text { 30/117 }\end{array}$ \\
\hline $\mathbf{2}$ & $\begin{array}{l}\text { Rohitaka mula } \\
\text { kalka (paste of root } \\
\text { powder) with } \\
\text { water }\end{array}$ & $\begin{array}{l}\text { Tecomella } \\
\text { undulata } \\
\text { (Sm.) }\end{array}$ & $\begin{array}{l}\text { Bhava } \\
\text { prakasha, } \\
\text { Chikitsa } \\
\text { sthana 69/7 }\end{array}$ \\
\hline $\mathbf{3}$ & $\begin{array}{l}\text { Amalaki beeja } \\
\text { kalka } \text { (paste of } \\
\text { seed powder) } \\
\text { mixed with honey } \\
\text { and sugar }\end{array}$ & $\begin{array}{l}\text { Emblica } \\
\text { officinalis } \\
\text { prakasha, } \\
\text { Ghikitsa } \\
\text { Sthana 69/7 }\end{array}$ \\
\hline $\mathbf{4}$ & $\begin{array}{l}\text { Nagakeshara with } \\
\text { takra (buttermilk) }\end{array}$ & $\begin{array}{l}\text { Mesua } \\
\text { ferrea } \\
\text { Linn. }\end{array}$ & $\begin{array}{l}\text { Yoga } \\
\text { Ratnakara, } \\
\text { Soma roga } \\
\text { chikitsa }\end{array}$ \\
\hline
\end{tabular}




\begin{tabular}{|c|c|c|c|}
\hline 5 & $\begin{array}{l}\text { Lodhra kalka } \\
\text { (paste of bark } \\
\text { powder) along } \\
\text { with Nyagrodha } \\
\text { Kashaya }\end{array}$ & $\begin{array}{l}\text { Symploco } \\
\text { S racemos } \\
\text { a Roxb. } \\
\text { Ficus } \\
\text { bengalens }\end{array}$ & $\begin{array}{l}\text { Charaka } \\
\text { Samhita, } \\
\text { Chikitsa } \\
\text { sthana, } \\
30 / 118\end{array}$ \\
\hline 6 & $\begin{array}{l}\text { Chakramarda } \\
\text { moola with } \\
\text { tandulodaka }\end{array}$ & $\begin{array}{l}\text { Cassia } \\
\text { tora Linn }\end{array}$ & $\begin{array}{l}\text { Yoga } \\
\text { Ratnakara, } \\
\text { Soma roga } \\
\text { chikitsa }\end{array}$ \\
\hline
\end{tabular}

The different formulations used in Shweta pradara are described in table. 4

\begin{tabular}{|c|c|c|}
\hline S.No & Formulation & Reference \\
\hline 1 & $\begin{array}{l}D a r v y a d i \\
k \text { watha }\end{array}$ & $\begin{array}{l}\text { Sharangadhara Samhita, } \\
\text { Madhyama khanda } 2 / 112\end{array}$ \\
\hline 2 & $\begin{array}{l}\text { Nyagrodhadi } \\
\text { kashaya }\end{array}$ & $\begin{array}{l}\text { Sushruta Samhita, } \\
\text { Sutrasthana } 38 / 49\end{array}$ \\
\hline 3 & $\begin{array}{l}\text { Pushyanuga } \\
\text { churna }\end{array}$ & $\begin{array}{l}\text { Charaka Samhita, Chikitsa } \\
\text { sthana, 30/90-96 }\end{array}$ \\
\hline 4 & Ashokarishta & $\begin{array}{l}\text { Bhaishajya Ratnavali, } \\
\text { Striroga adhikara 114-116 }\end{array}$ \\
\hline 5 & $\begin{array}{l}\text { Lakshmanarish } \\
\text { ta }\end{array}$ & $\begin{array}{l}\text { Bhaishajya Ratnavali, } \\
\text { Pradara roga 565/115-117 }\end{array}$ \\
\hline 6 & Patrangasava & $\begin{array}{l}\text { Bhaishajya Ratnavali, } \\
\text { Pradara Chikitsa 122-126 }\end{array}$ \\
\hline 7 & Lodhrasava & $\begin{array}{l}\text { Ashtanga Hridaya Chikitsa, } \\
12 / 24-27\end{array}$ \\
\hline 8 & Ashoka ghrita & $\begin{array}{l}\text { Bhaishajya Ratnavali, } \\
\text { Pradara Chikitsa 17-21 }\end{array}$ \\
\hline 9 & $\begin{array}{l}\text { Ka ly a n a ka } \\
\text { ghrita }\end{array}$ & $\begin{array}{l}\text { Ashtanga Hridaya } \\
\text { Uttaratantra 6/26-28 }\end{array}$ \\
\hline 10 & $\begin{array}{l}\text { Suk } и \text { m } m \text { a } r a \\
\text { grhrita }\end{array}$ & $\begin{array}{l}\text { Ashtanga Sangraha } \\
\text { Chikitsasthana } 15 / 20\end{array}$ \\
\hline 11 & $\begin{array}{l}\text { Kadali Kanda } \\
\text { ghrita }\end{array}$ & $\begin{array}{l}\text { Yoga Ratnakara, Somaroga } \\
\text { chikitsa }\end{array}$ \\
\hline
\end{tabular}

Bahyaprayogas: (External administration): (23)

- Yoniprakshalana (Vaginl Irrigation) - done with drugs like Lodhra (Symplocos racemosa Roxb.) \& Vata (Ficus bengalensis Linn) twak kashaya, Triphala kwatha (Terminalia chebula Retz , Terminalia bellirica. Roxb and Emblica officinalis Gaertn decoction) with takra (buttermilk) etc.

- Vartidharana (Suppository) - After oleating the vaginal canal, suppository made with Lodhra (Symplocos racemosa Roxb), Priyangu (Callicarpa macrophylla Vahl) \& Madhuka (Madhuca indica J.F.Gmel.) should be kept in yoni (Vaginal canal).

- Avachurnana (Sprinkling with powder)- Khadira (Acacia catechu (Linn.f.)), Pathya (Terminalia chebula Retz), Jatiphala (Myristica fragrans Henlt.), \& Nimba (Azadirachta Indica A.Juss) churna, Panchavalkala churna (Vata (Ficus bengalensis Linn.), Ashwatha (Ficus religiosa Linn.), Udumbara (Ficus glomerata Roxb),Plaksha (Ficus lacor Buch-Ham.), Parish (Thespesia populenea Soland. ex Correa.) Though it is mentioned under avachurnana, it is best used as prakshalana (Vaginal irrigation).

- Pichudharana (Tampoons)- Nyagrodha or Vata (Ficus bengalensis Linn) \& Lodhra (Symplocos racemosa Roxb), twak kashaya is placed in the yoni (Vaginal canal) as pichu or tampoon.

- Yoni Dhupana - Dhupana (Fumigation) with Sarala (Pinus roxburghii Sarg), Guggulu (Commiphora mukul Hook. Ex Stocks) and Yava (Hordeum vulgare Linn) mixed with Ghrita (ghee) should be done after oleating the genitals.

\section{Observational Study}

- 50 patients who attended the OPD of Prasuti tantra at Sir Sundarlal Hospital, IMS, BHU were studied as per the diagnostic criteria of Shweta pradara.

- Duration of Study: 6 months

- Sample size: 50

- Method of collection of data: Structured questionnaire, examination and vaginal swab.

- Inclusion criteria: All women between the age group-15-45 years, complaining of leucorrhoea, irrespective of pathology.

- Exclusion criteria: Pregnancy, Pelvic inflammatory disease and Sexually transmitted disease, Post menopausal women, cervical erosion.

- Different subjective parameters assessed in the subjects using a questionnaire are described in table 5.

Table 5: Subjective parameters assessed in questionnaire

\begin{tabular}{|c|c|c|c|c|c|}
\hline S.No & Criteria & 3 & 2 & 1 & $\mathbf{0}$ \\
\hline 1.1 & $\begin{array}{l}\text { Yoni srava } \\
\text { (Discharge) }\end{array}$ & $\begin{array}{l}\text { Severe (requires pad, } \\
\text { severe irritation }\end{array}$ & $\begin{array}{l}\text { Moderate (needs to } \\
\text { change undergarment) }\end{array}$ & Mild-no irritation & Absent \\
\hline 1.3 & $\begin{array}{l}\text { Yoni kandu } \\
\text { (Pruritis) }\end{array}$ & $\begin{array}{l}\text { Severe (unrelieved by } \\
\text { scratching, excoriation) }\end{array}$ & $\begin{array}{l}\text { Moderate (relief by } \\
\text { scratching, without } \\
\text { excoriations) }\end{array}$ & $\begin{array}{l}\text { Mild without need } \\
\text { to scratch }\end{array}$ & Absent \\
\hline 1.4 & $\begin{array}{l}\text { Kati shola } \\
\text { (Back ache) }\end{array}$ & $\begin{array}{l}\text { Severe (continuous } \\
\text { pain does not } \\
\text { relieve by rest }\end{array}$ & $\begin{array}{l}\text { Moderate } \\
\text { (mildly hampers daily } \\
\text { work, relieves by rest) }\end{array}$ & $\begin{array}{l}\text { Mild-(doesn't } \\
\text { hamper physical } \\
\text { work) }\end{array}$ & Absent \\
\hline 1.5 & $\begin{array}{l}\text { Maithuna } \\
\text { Asahishnutha } \\
\text { (Dyspareunia) }\end{array}$ & $\begin{array}{l}\text { Severe, pain leading to } \\
\text { apareunia }\end{array}$ & $\begin{array}{l}\text { Moderate, Pain } \\
\text { prevents coitus } \\
\text { in most occasions }\end{array}$ & $\begin{array}{l}\text { Mild -pain } \\
\text { doesn't prevent } \\
\text { penetration }\end{array}$ & Absent \\
\hline
\end{tabular}




\section{Observations and Discussion}

Among 50 patient included in this study, $2 \%$ of patients were in the age group $15-20 \mathrm{yrs}, 6 \%$ in $21-25 \mathrm{yrs}, 4 \%$ in $26-30 \mathrm{yrs}, 36 \%$ in $31-35 \mathrm{yrs}, 42 \%$ in $36-40 y r s$ and $10 \%$ in $41-45 y$ rs respectively. $84 \%$ of patients were Hindus and $16 \%$ were Muslims. Based on educational status $12 \%$ had primary education, $56 \%$ were high school, $26 \%$ were graduates and $6 \%$ uneducated. Among 50 patients $86 \%$ were homemakers and $14 \%$ were working women. $52 \%$ belonged to lower class and $46 \%$ patients belonged to middle class and $2 \%$ under upper socio economic status. Based on hygiene $94 \%$ maintained good hygiene and $6 \%$ had poor hygiene. $92 \%$ of the patients had regular menstruation and $8 \%$ had irregular menstruation. $60 \%$ had history of normal vaginal delivery, $30 \%$ delivered by caesarean section and $10 \%$ patient were nulliparous. $46 \%$ of the total patients were sterilized, $6 \%$ were using copper-T, $20 \%$ of patients were using other methods of contraception and $28 \%$ used no method of contraception. Among the 50 patients, $22 \%$ were para 1 , $46 \%$ were para $2,16 \%$ para 3 and $6 \%$ were para 4 and $10 \%$ were nulliparous.

Incidence according to onset of yoni srava (Vaginal discharge):Among the 50 patients, $76 \%$ of them had gradual onset of srava and $24 \%$ had sudden onset.

Incidence according to periodicity of srava (Vaginal discharge): $72 \%$ patients had yoni srava continuously throughout the menstrual cycle, $6 \%$ had srava in the mid cycle, $8 \%$ complained of srava after menses and $7 \%$ had intermittent srava.

Incidence according to odour: In this study among 50 patients $94 \%$ had non offensive discharge and $6 \%$ had offensive odour.

Incidence according to the grading of yoni srava (Vaginal discharge): Among 50 patients included in this study, $68 \%$ patients had mild yoni srava and $32 \%$ had moderate srava.

Incidence according to yoni kandu (Pruritis): Among the 50 patients, $80 \%$ patients didn't complain of yonikandu and $20 \%$ had mild kandu.

Incidence according to katishoola (Back ache): Among 50 patients, $90 \%$ did not complain of katishoola, and only 10\% had mild katishoola.

Incidence according to maithuna asahishnutha (Dyspareunia): In this study among 50 patients, 94\% patients didn't complain of maithuna asahishnutha and only $6 \%$ had mild symptom.

Incidence of different microorganisms in Shweta pradara cases: The incidence of different microorganisms in the observational study based on the vaginal swab are described in table. 6
Table 6: Incidence of different micro organisms in Shweta pradara cases

\begin{tabular}{|c|c|c|c|}
\hline S.No & $\begin{array}{l}\text { Organisms Isolated } \\
\text { from Vaginal swab }\end{array}$ & $\begin{array}{l}\text { No. of } \\
\text { cases }\end{array}$ & $\begin{array}{l}\text { Percent } \\
\text { age }\end{array}$ \\
\hline 1 & No organism isolated & 14 & $28 \%$ \\
\hline 2 & Staphylococci & 5 & $10 \%$ \\
\hline 3 & Escherichia coli & 10 & $20 \%$ \\
\hline 4 & Klebsiella & 1 & $2 \%$ \\
\hline 5 & Pseudomonas & 2 & $4 \%$ \\
\hline 6 & Candidial species & 9 & $18 \%$ \\
\hline 7 & $\begin{array}{l}\text { Trichomonas } \\
\text { vaginalis }\end{array}$ & 3 & $6 \%$ \\
\hline 8 & Streptococci & 2 & $4 \%$ \\
\hline 9 & Micrococci & 4 & $8 \%$ \\
\hline
\end{tabular}

The present study showed the wide distribution of the patients of shweta pradara. As suggested in the samhitas, shweta pradara is not merely a symptom inclusive of vaginal discharge, but it is mostly the presenting feature of an underlying pathology and may be associated with other symptoms like blood or pus mixed discharge, malodor and pruritis. Moreover on isolation of the micro-organism from the vaginal swab, many at times association with different varieties of micro-organism is noted.

\section{Conclusion}

The present study has shown clearly that shweta pradara is mostly a polymicrobial infection. The study has also shown that incidence of shweta pradara is associated with age, parity, other clinical signs and symptoms and involved micro-organism. Thus, before indulging into the treatment of shweta pradara, it becomes mandatory to understand the associated symptoms and the pathology involved and investigate thoroughly, frequently and regularly.

\section{Sources of funding: None.}

\section{Conflict of interest: None}

\section{References}

1. Gupta V. et.al. Clinical spectrum and microbial etiology or reproductive tract infections in rural women in the hills of North India. Jr of obstet \& Gynaecol of India. Jan-Feb, 2002; 52(1); 130-134.

2. Vidya JC, Wilson $J$ et al. Global epidemiology of Leucorrhoea. Curr J of Gynol. 2010; 4(21):34-38.

3. Hakakha MM, Davis J, Korst LM et al. Leukorrhea and Bacterial Vaginosis as in-office predictors of cervical infection in high-risk women. Obstet Gynecol. 2002; (100):808-812.

4. Demirezen S, Safi Z, Beksac S. The interaction of Trichomonas Vaginalis with epithelial cells, polymorphonuclear leucocytes and erythrocytes on vaginal smears: light microscopic observation. Cytopathology. 2000; (11):326-332.

5. Raja Radha Kanta Dev. Shabda Kalpa Drum. 3 $3^{\text {rd }}$ Edition. Varanasi; Chowkhamba Sanskrit series office; $1967.431 \mathrm{p}$

6. Jadavaji Trikamji Acharya. Charaka Samhita of Acharya Agnivesa with Ayurveda Dipika 
Commentary by Chakrapanidatta. Chikitsa Sthana, 30/11. 1st Edition. Varanasi; Chaukhamba Surbharati prakashan; 2000.635p.

7. Jadavaji Trikamji Acharya. Charaka Samhita of Acharya Agnivesa with Ayurveda Dipika Commentary by Chakrapanidatta. Chikitsa Sthana, 30/22. 1st Edition. Varanasi; Chaukhamba Surbharati prakashan; 2000.635p.

8. Jadavaji Trikamji Acharya. Charaka Samhita of Acharya Agnivesa with Ayurveda Dipika Commentary by Chakrapanidatta. Chikitsa Sthana, 30/218. 1 $1^{\text {st }}$ Edition. Varanasi; Chaukhamba Surbharati prakashan; 2000. 643p.

9. Jadavaji Trikamji Acharya. Charaka Samhita of Acharya Agnivesa with Ayurveda Dipika Commentary by Chakrapanidatta. Chikitsa Sthana, 30/222. 1st Edition. Varanasi; Chaukhamba Surbharati prakashan; 2000. 643p.

10. Jadavaji Trikamji Acharya. Charaka Samhita of Acharya Agnivesa with Ayurveda Dipika Commentary by Chakrapanidatta. Chikitsa Sthana, 30/13. 1 st Edition. Varanasi; Chaukhamba Surbharati prakashan; 2000. 635p.

11. Jadavaji Trikamji Acharya. Charaka Samhita of Acharya Agnivesa with Ayurveda Dipika Commentary by Chakrapanidatta. Chikitsa Sthana,30/222. 1st Edition. Varanasi; Chaukhamba Surbharati prakashan; 2000. 643p.

12. Jadavaji Trikamji Acharya. Charaka Samhita of Acharya Agnivesa with Ayurveda Dipika Commentary by Chakrapanidatta. Chikitsa Sthana, 30/116. $1^{\text {st }}$ Edition. Varanasi; Chaukhamba Surbharati prakashan; 2000. 639p.

13. Shivprasad Sharma. Astanga Samgraha of Vrddha Vagbhata with shashilekha Commentary by Indu. Uttarasthana, 39/96. $1^{\text {st }}$ Edition. Varanasi; Chaukabha Sanskrit Series Office; 2008. 839p

14. Parasurama Sastri Vidyasagar. Sharangadhara Samhita of Acharya Sharangadhara with Commemntary -Adhamallas Dipika and Kashiramas Gudhartha Dipika. Prathama Khanda, 7/177-179. $1^{\text {st }}$ Edition. Bombay; Tukaram Javaji, proprietor of Nirnaya-sagar press; $1931.127 \mathrm{p}$.
15. Brahma Sankara Misra. Bhavaprakasha of Sri Bhavamishra with Vidyotini Hindi Commentary.

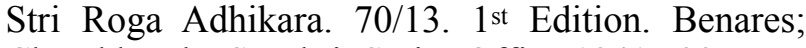
Chowkhamba Sanskrit Series Office;1941.799p

16. Krishna Sharma. Yoga Ratnakara.Yonivyapad roganaam chikitsa/11. $1^{\text {st }}$ Edition. Bombay; Tukaram Javaji, proprietor of Nirnaya-sagar press; 1907. 451p.

17. Jadavaji Trikamji Acharya. Charaka Samhita of Acharya Agnivesa with Ayurveda Dipika Commentary by Chakrapanidatta. Chikitsa Sthana, 30/13.1 ${ }^{\text {st }}$ Edition. Varanasi; Chaukhamba Surbharati prakashan; 2000. 635p.

18. Jadavaji Trikamji Acharya. Charaka Samhita of Acharya Agnivesa with Ayurveda Dipika Commentary by Chakrapanidatta. Chikitsa Sthana, 30/15.1 st Edition. Varanasi; Chaukhamba Surbharati prakashan; 2000. 635p.

19. Jadavaji Trikamji Acharya. Charaka Samhita of Acharya Agnivesa with Ayurveda Dipika Commentary by Chakrapanidatta. Chikitsa Sthana, 30/21.1 st Edition. Varanasi; Chaukhamba Surbharati prakashan; 2000. 635p.

20. Jadavji Trikumji Acharya. Sushruta Samhita of Acharya Sushruta with Nibandhasangraha Commentary by Dalhana. Uttaratantra, 38/15-17. 1st Edition. Bombay; Tukaram Javaji, proprietor of Nirnaya-sagar press; $1915.564 \mathrm{p}$.

21. Jadavji Trikumji Acharya. Sushruta Samhita of Acharya Sushruta with Nibandhasangraha Commentary by Dalhana. Uttaratantra, 38/13. 1st Edition. Bombay; Tukaram Javaji, proprietor of Nirnaya-sagar press; 1915. 564p.

22. Jadavaji Trikamji Acharya. Charaka Samhita of Acharya Agnivesa with Ayurveda Dipika Commentary by Chakrapanidatta. Chikitsa Sthana, 30/12.1 st Edition. Varanasi; Chaukhamba Surbharati prakashan; 2000. 635p.

23. Jadavaji Trikamji Acharya. Charaka Samhita of Acharya Agnivesa with Ayurveda Dipika Commentary by Chakrapanidatta. Chikitsa Sthana, 30/117-120.1 $1^{\text {st }}$ Edition. Varanasi; Chaukhamba Surbharati prakashan; 2000. 639p. 